\title{
Computing for democracy: The Asociación de Técnicos de Informática and the professionalization of computing in Spain
}

\author{
Luís Duque
}

Independent researcher, Barcelona, Spain

\section{Jordi Fornés}

BarcelonaTech / Universitat Politècnica de Barcelona, Barcelona, Spain

\section{Néstor Herran}

Sorbonne Universités / Université Pierre et Marie Curie, Paris, France

Abstract: The professionalization and institutionalization of computing in Spain had a turning point in the mid-1970s, resulting from the crisis of Franco's dictatorship and the establishment of a constitutional democracy in 1976. One of the key players was the Association of Information Technology Technicians (Asociación de Técnicos de Informática, ATI), whose activities included demands for better working conditions in the computing industry, the promotion of academic programs in computer sciences and the lobbying for the regulation of computing to preserve privacy and personal freedom. In contrast with Europe and the United States, where the Information Technology sector grew without professionalization, nor unionism, ATI's claims and commitments were coherent with wider cultural, economic and political changes in the country, and were inspired by the climate of contemporary left-wing opposition to the Francoist regime in Catalonia. However, once democracy was established, the political and trade union activism of the Association declined to almost disappear.

\section{Introduction}

On October 4th 1967, 31 computing professionals meet at the headquarters of the FrenchSpanish Association for Scientific and Technical Cooperation (Asociación Hispano-Francesa de Cooperación Técnica y Científica) in Barcelona ${ }^{1}$. Most of them were industrial engineers, members of the National Association of Industrial Engineers (Asociación Nacional de Ingenieros Industriales, ANII) ${ }^{2}$, which had usually made postgraduate studies in France ${ }^{3}$. Earlier in the year, they had set up informal contacts to assess the state of computing training and industry in Spain and discuss the establishment of formal structures for supporting professionalization, a challenging action under civic-rights limiting Franco's dictatorship. Participants in the meeting come to the idea of creating an association by using a legal loophole, that is, by establishing a socalled Technical Commission of Computing (Comisión Técnica de Informática) as part of the ANII. The resulting group was called Association of Information Technology Technicians (Asociación de Técnicos de Informática, ATI), and became the first Spanish association representing computer professionals.

The main goals of the ATI were expressed in a chart, which stated that it would "facilitate among partners the interchange of experiences and information about computing techniques", "create 
working groups to perform work or research on these topics", "perform demonstrations, seminars and conferences on these topics, cooperate with others organizers, and publish with and assist the publication of the results", "promote dissemination in Spain of computing techniques", and "make contacts with national and international associations related to establish collaborations within these topics". It also stressed that the association was "committed to nonprofit activities and independent of any commercial entity". In a market dominated by IBM, the foundational members of the ATI wanted to build an abstract knowledge independent from any manufacturer. This choice was reflected in the adoption of a new name for their discipline, choosing the word informática instead of electronic data processing, a term closely associated with IBM. They also added "technicians" in their name, a word expressing their commitment to the building of a specific knowledge and to professionalization ${ }^{4}$. All computing professionals were invited to join the association, being no mandatory having a University degree, but only two years of experience in computing ${ }^{5}$.

Six years later, by the end of 1973, the ATI counted with 556 members and fulfilled its training support dimension by organizing about ten courses and seminars per year. In December 1974, under the determined impulse of Julian Marcelo-Cocho, the association further advanced in this goal by establishing its own publication, the journal Novática, which initially appeared as a supplement of Novatecnia, the journal of the ANII.

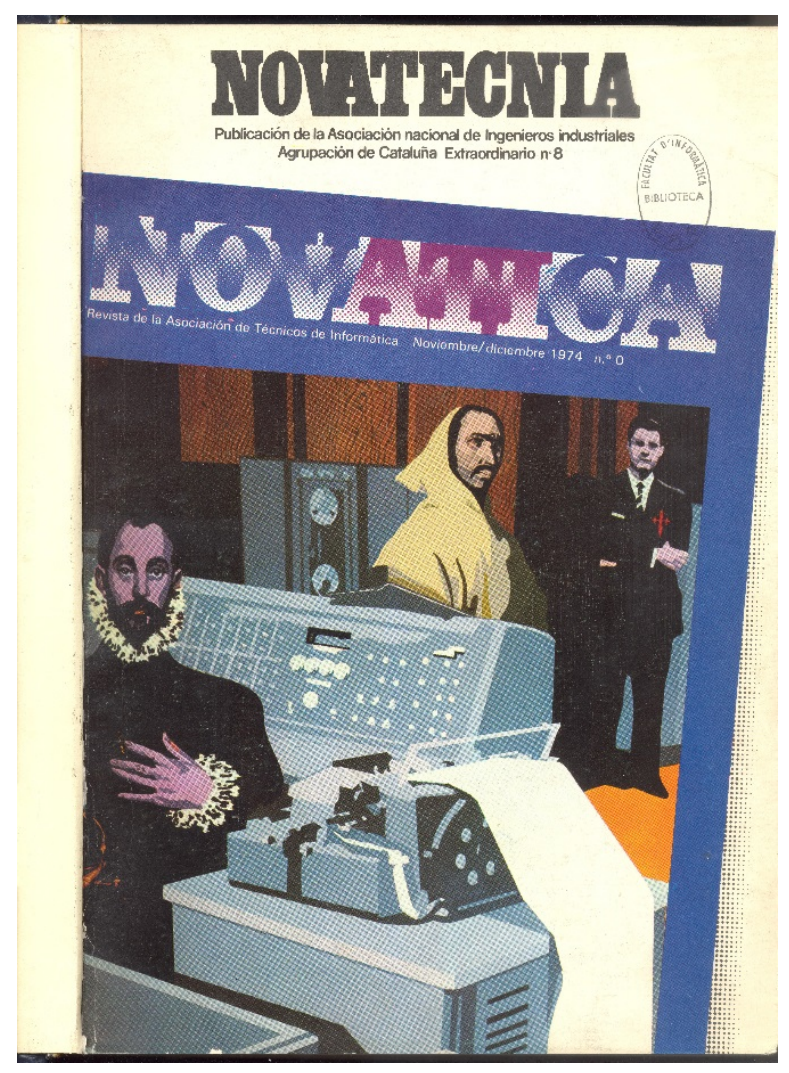

Figure 1. Front cover of the first issue of Novática. The title of the journal combines the name of the ANII journal (NOVAtecnia) with the acronym of the new association (ATI) and the word "informATICA". The cover reproduces the painting Las estructuras cambian, las esencias permanecen ["Structures change, essences remain", 1968], by Manuel Valdés \& Rafael Solbes (Equipo Crónica), pioneers of Spanish pop Art.

The expansion of ATI was simultaneous with a political transition in Spain from a military 
dictatorship to a constitutional democracy, as well as an economic one resulting from the impact of 1973 on the Spanish economy and a cultural and social one inspired by events in European countries $^{6}$. A climate of social unrest, political change and unleashed activism was a fertile ground for the entanglement of professional and political claims, to which members of the ATI were not spared. The strong links between Spanish leftist movements opposed to the regime, and the emergence of computing as a profession can be revealed from the selection of topics in Novática's articles, covering the creation of trade unions, the improvement of salaries, equal rights for women and handicapped people or the respect of regional languages and medical coverage, and indeed in the editorials, which called for the defense of democracy and reflected upon the ethical problems of electronic data processing.

This interaction between the institutionalization of computing and political involvement bears similitude -but also important differences- with other cases analyzed by academic historians. For example, Slava Gerovitch has studied the institutionalization of computing in the Soviet Union, showing that soviet cybernetics become part of a social movement for radical reform in science and society, criticized under Stalin as a weapon of imperialist ideology and rehabilitated under Khrushchev to be hailed as a "science in the service of communism". For Gerovitch, these changes reveal the changing power relations within the scientific community and in the political role of scientists and engineers in Soviet society ${ }^{7}$. In the United States, Paul Edwards has shown how computing enabled the formation and pursuit of Cold War politics, and how computer metaphors shaped American intellectual life $^{8}$. Also regarding the American case, Fred Turner history of the Whole Earth Catalog has shown how the counterculture movement of the late 1960s and early 1970s accompanied the transformation of the image of computing from a Cold war product to a guarantee of individualism and democracy ${ }^{9}$. Finally, Eden Medina has studied the importance of Cybersyn, a project lead by the British cyberneticist Stafford Beer for Salvador Allende, democratic president of Chile from 1970 until the coup d'état of 1973. Cybersyn aim was to help to implement the transition of Chile's economy from capitalism to socialism, and was instrumental to avoid the collapse of economy during a truck divers strike in $1972^{10}$.

Our case study provides an opportunity to connect some of the themes evoked in this literature with classical approaches about the process of professionalization taken from the history and sociology of professions. A good departure point can be Abbott's "ecological" view, which explains the emergence of a profession from processes of differentiation within occupations, its configuration by means of struggle at different levels (the workplace, culture, public opinion, and legal and administrative rules), and its consolidation through conflict between different technical communities mediated by jurisdictional claims ${ }^{11}$. Inspired by this view, Nathan Ensmerger has studied the "failed" professionalization of computing in the 1960s, a period characterized by the unsuccessful efforts by computer programmers to achieve "control over entry into the profession, and the adoption of a shared body of abstract occupational knowledge" ${ }^{\prime 2}$. However, they also resisted the desire of corporate managers to transform them in a standardized, tractable workforce. According to Ensmerger, the resulting, undefined situation of computer programmers arising from this conflict leads to characterize them as technicians, which Stephen Barley define as a category constituted by white-collar workers with scientific or engineering training, but that also value craft knowledge. These workers play an important role as mediators between the technological and social architectures of the organizations, conducting sophisticated scientific and mathematical analyses, and are granted quite a lot of autonomy by their employers ${ }^{13}$.

IT workers in Spain encountered similar problems, but in this case the move to professionalization encouraged by the government policy was perceived as a way to disempower 
and control computing workforce, and therefore ATI developed a strong opposition via ANSAPI and Novática ${ }^{14}$. In this case, the adoption of the name "technician" to describe their work was instrumental in their fight against corporations and the State, by helping them to keep away a "professionalization" that, from their point of view, meant control and division of the computing labor force ${ }^{15}$. Here, the main difference with the American case studied by Ensmerger is the key role of the State in the definition of professions, and the instability of the political background due to the end of the dictatorship and the transition to democratic regime. As we will see, the political involvement of the leaders of the IT community was strong in Spain during the transition to democracy, but restrained to local settings and short time spans. Once democracy was established, we found ATI members as university lecturers or well positioned professionals in the IT industry, but none of them as politicians. After being very prominent for some time, political discourses eventually faded and leave place to standard discipline-building activities, mostly focused on university institutionalization and professional lobbying.

In order to show this gradual transition, we focus on the first years of $\mathrm{ATI}^{16}$, which we have just described as the main professional association of computer professionals in Spain. By closely following the activities and debates in which this association was involved, we aim to reveal the ties between the political context and the process of professionalization of computing in late Francoism. The argument unfolds in three parts: first, we describe the Spanish political context in late 1970s and try to understand ATI's activities supporting computer professionals' rights; then, we focus on the involvement of ATI in the creation of the first university studies in computing in Barcelona; finally, we study ATI's lobbying activities with political parties and its influence in legislation, and especially in the inclusion of a reference to computing in the Spanish constitution.

\section{Politics, labor and computing in Franco's Spain}

The creation of the ATI and its early activities can be better understood by taking into account the context of labor regulations and the expansion of computing in Spain by the mid-1970s. In the early 1970s, the country was a political anomaly in Western Europe. A fascist military dictatorship, led by General Franco since 1939 after a Civil War provoked by a right-wing coup d'état in 1936, had survived the defeat of their supporting Axis powers in World War 2 by realigning itself as a close ally of the United States during the Cold War. Despite maintaining a totalitarian attitude regarding social mores, religion and political rights, its economy had evolved from autarky to a relative openness to foreign commerce following the 1953 USA-Spain agreements. From 1959, a new customs tariffs policy and an International Monetary Fund (IMF)inspired stabilization plan implemented a new economic policy that -on the basis of cheap salaries, low taxes, foreign investment and the development of tourism -led to the so-called "Spanish economic miracle"17.

Since the establishment of General Franco's rule, labor relationships were initially molded on fascist and Nazi models, which banned free trade unions and established a state-controlled organization. The Spanish Union Organization (Organización Sindical Española, OSE, also known as Sindicato Vertical) regulated the relations between workers and their employers by controlling and monitoring workers, served the state's surveillance goals by informing the government when a problem occurred in production, and performed bureaucratic tasks on labor administration such as collecting economic statistics ${ }^{18}$. The OSE, interestingly, was a key target of the underground Spanish Communist Party and its associated trade union Comisiones Obreras, CCOO (Workers' Commissions), which abandoned armed resistance since the early 1950 s and tried to 
undermine the regime from inside, by infiltrating its members as representatives in the organization $^{19}$.

The role of OSE in structuring labor relationships, which was tightly enforced during the autarkic period, began to deteriorate when the regime's economic policies evolved in the late 1950s, in particular with the establishment in 1958 of a new law allowing collective agreements (Ley de Convenios Colectivos ${ }^{20}$, which allowed for the existence of negotiation inside companies. Indeed, the Civil Code was reformed in 1965 following an important wave of miners' strikes in 1962 and international pressure. Strikes, which were strictly forbidden in early Francoism -they were assimilated to the crime of sedition- were decriminalized if they were strictly related with workers' economic demands ${ }^{21}$.

In relation to computing, the Spanish market was dominated by machines produced in the United States. In the autarky period (1939-1953), IBM (and before although not yet with that name) almost monopolized the Spanish market. IBM stated its supremacy in the Spanish market in three legs that complemented each other perfectly; the quality and comprehensiveness of its systems, which took into account the whole life product, from pre-sales services to the installation and start-up ${ }^{22}$; the aggressiveness of its marketing campaigns, which had important echo in Spanish newspapers ${ }^{23}$; and its multinational policy, that officially rejected bribery and compromise with authoritarian regimes, but also knew how to please the governments installing new factories or sale offices ${ }^{24}$. Most companies gradually replaced their electromechanical tabulating machines by electronic models such as the IBM 609 (continuation from 604, but transistorized) and Bull 300. By 1952, Guillermo Turinger's Company began to sell Bull machines, the two first being acquired by the government administration in 1953. Bull Gamma 3 fought against the IBM 604 and the IBM's market share fell to $70-80 \%$ by the end of the decade, still with tabulating machines.

In 1959 , the Spanish government presented a stabilization plan to the International Monetary Fund, which abandoned hopes of autarkic development and eased the import of foreign technology ${ }^{25}$. As a result, Spanish companies had access to foreign goods at prices that, on average, were halved ${ }^{26}$. Economic stabilization boosted Spanish industrialization in general and computerization in particular. Between 1959 and 1961, the number of tabulating machines increased by $50 \%{ }^{27}$. The first computers were imported in late 1950 s to be implemented in Spanish public corporations, such as the National Railway Company (Red Nacional de Ferrocarriles Españoles, RENFE), which acquired an IBM 650 in 1958, and the National Nuclear Research Institution (Junta de Energía Nuclear, JEN), which acquired an UNIVAC UCT in 1959. However, these big computers were not representative of the business model followed by Spanish companies in the process of mechanization (a word commonly used before the IBMinspired expression "electronic data processing" spread), as it was focused on gradually replacing accounting machines by electronic versions, and expand the market to new kinds of users.

An example of this strategy was IBM 1401, which was presented at the Barcelona trade fair in 1961 , and its subsequent competitor, the Bull Gamma $10^{28}$. By mid-1960s, IBM had recovered its dominant position, achieving a maximum share of $90 \%$ of the market. In the $1970 \mathrm{~s}$, the emergence of new competitors (NCR, Siemens), the highest penetration of old (Univac, Honeywell-Bull), and especially the change in purchasing policies of banks, the state and public companies reduced this quota. Still, IBM was by large the first in the ranking, both in revenues as in number of installed machines, followed by Univac (in revenues) or by Honeywell-Bull (in equipment). As figure 3 shows, the rest of manufacturers represented a few piece of the market. Computers also spread in sectors of Spanish industry such as banking or telecommunications, leading to the development of a community of workers involved in computing tasks that, by 
1971, attained 11,551 people ${ }^{29}$. As shown in figure 4, most of them were assistants and manual operators, including an important-and much feminized- workforce of keypunchers.

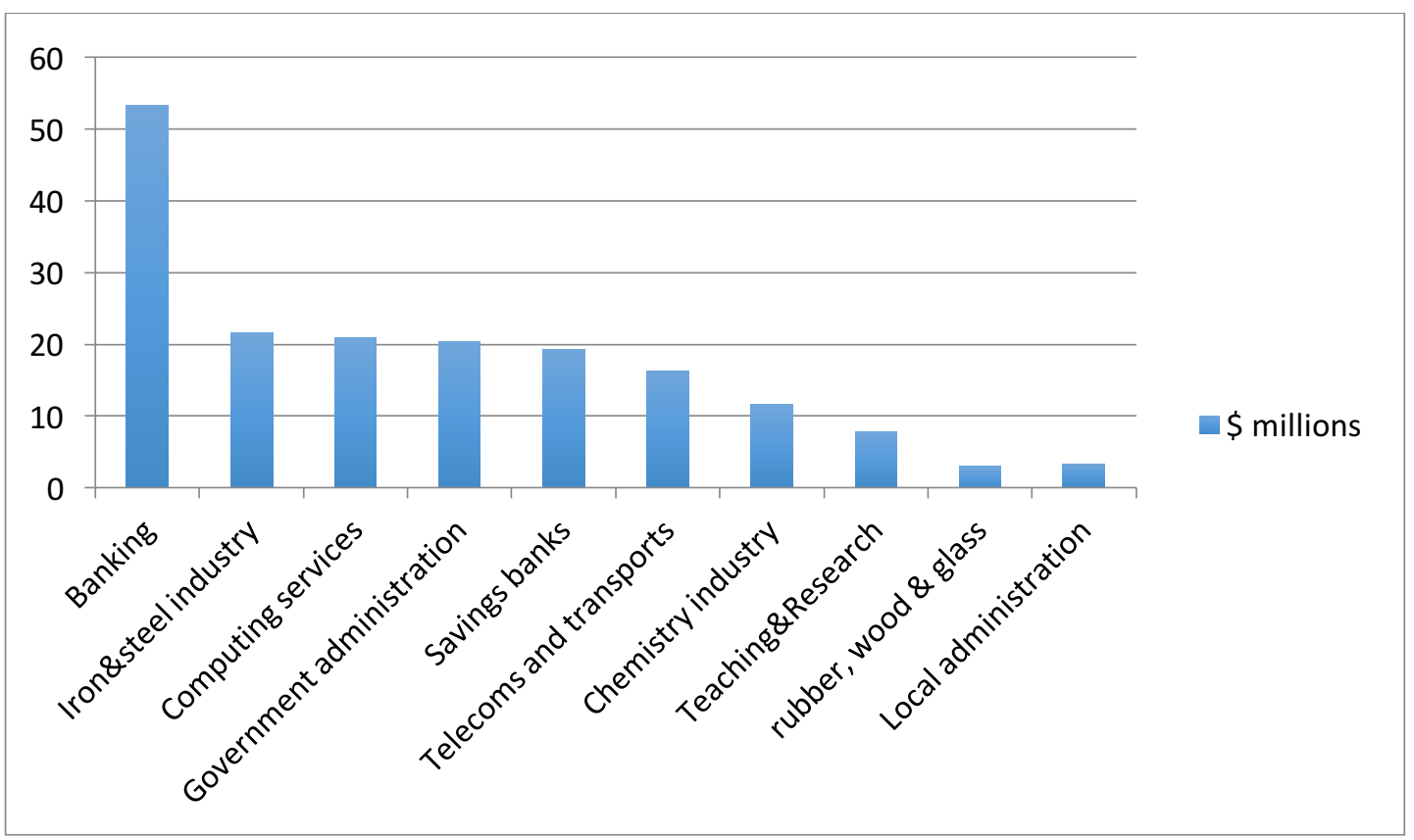

Figure 2. Investments in computing by activity sector, 1972. Source: Presidencia del Gobierno, La Informática en España, Servicio Central de Informática, 1973.

\section{Revenues}

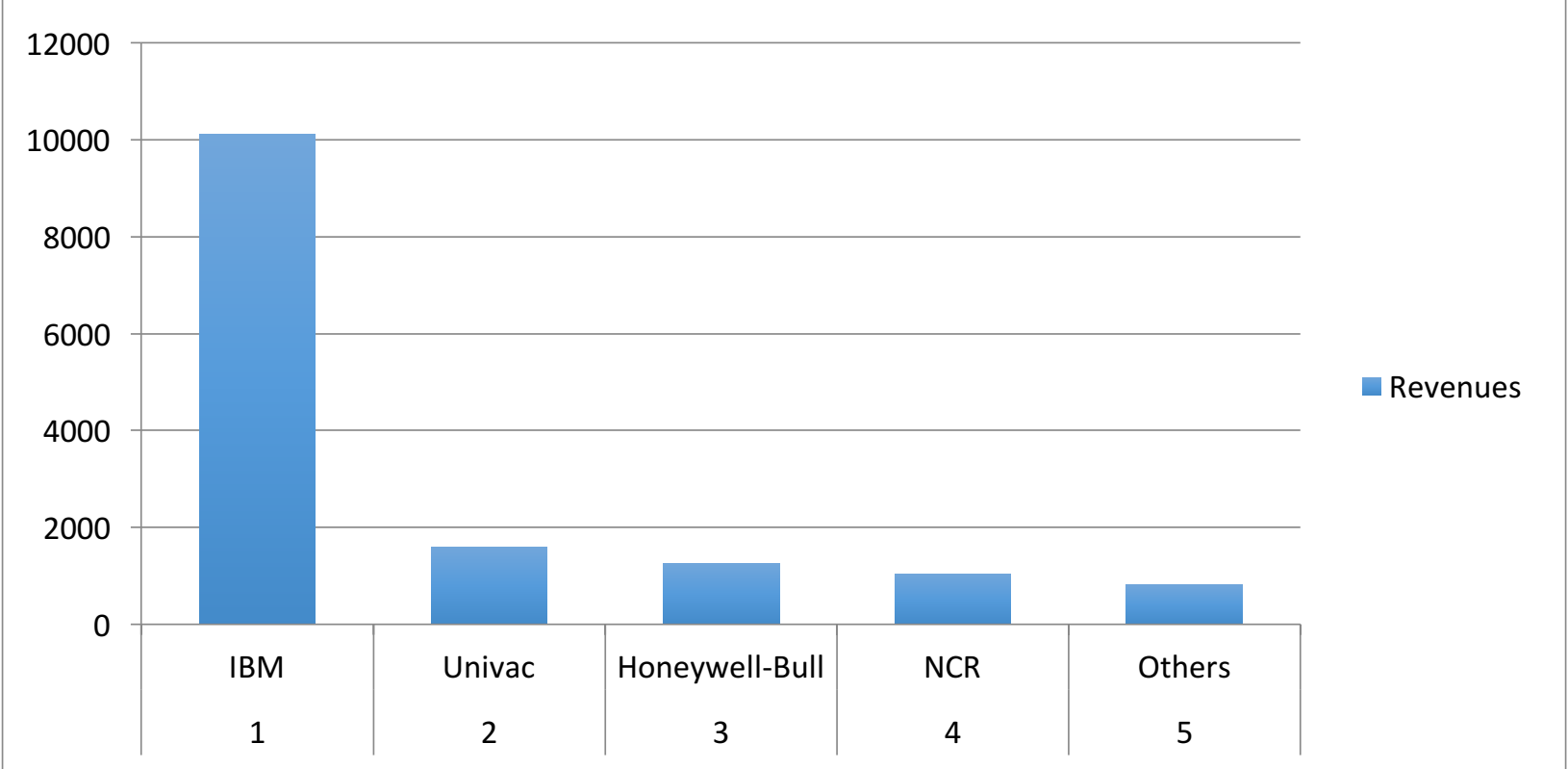

Figure 3. Ranking of manufacturers by revenues in 1975. Source: Presidencia del Gobierno, La Informática en España 1976, Servicio Central de Informática, 1977. 


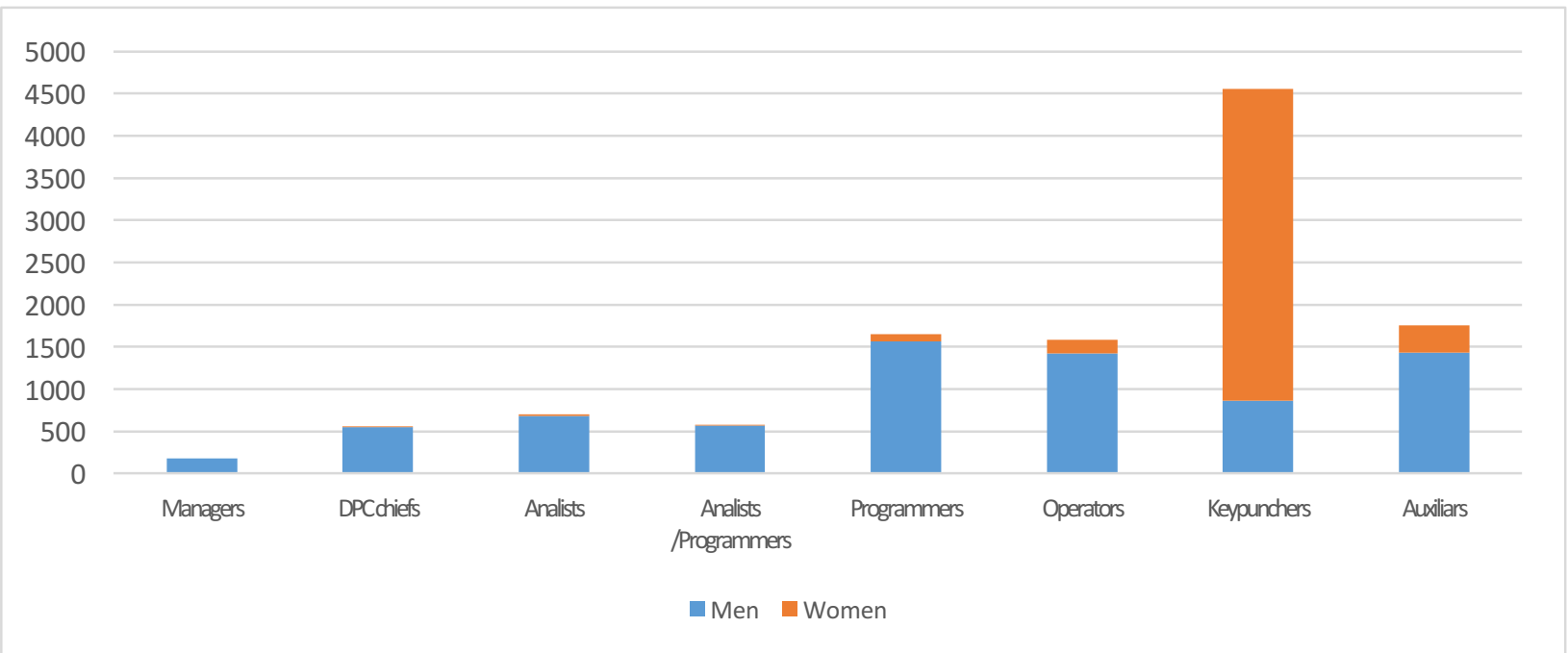

Figure 4. Workers related to computing in Spain by 1971. Source: Presidencia del Gobierno, La informática en España, Servicio Central de Informática, 1973.

The Americanization of the computer market in Spain led to training structures for new professionals in computing very similar than those developed in the United States one decade before $^{30}$. In Spain, as well as in the USA, computer manufacturers established and controlled training practices, making entry tests for potential recruits, running training courses and designing the syllabi. Indeed, as in the United States, manufacturers alone could not produce enough trained programmers to keep with industry's needs, leading to increasing salaries and programmers' claims for professional recognition. Fast computerization put workers of Spanish data centers in good bargaining position, and consequently they enjoyed a situation similar to their American counterparts ten years earlier: decent salaries, relative autonomy and easy mobility in a context in which headhunting was quite common. Situated in an independent space between blue and white collar workers, they mastered an art -programming- that few people could understand inside the company. From the companies' point of view, electronic data processing was considered as a tool critical for the modernization, automation and reduction of costs, and they did not promote any division of labor or professionalization among computer workers at least until the early 1970s, when the first collective agreements listed were signed and established different computer categories ${ }^{31}$.

In this context, founding members of the ATI shared a concern for legitimizing their profession, and to get some autonomy from hardware manufacturers. This desire of independence was expressed in the two main points of the chart of the: improved training, which meant learning programming techniques independently from any manufacturer, and defense of better labor conditions. In this respect, it is important to remember that the ATI was born in Barcelona, which was not only one of the most important industrial centers of Spain, counting a thriving community of computer technicians (see figure 6), but also a highly mobilized society in terms of activism and opposition to the dictatorship ${ }^{32}$. 


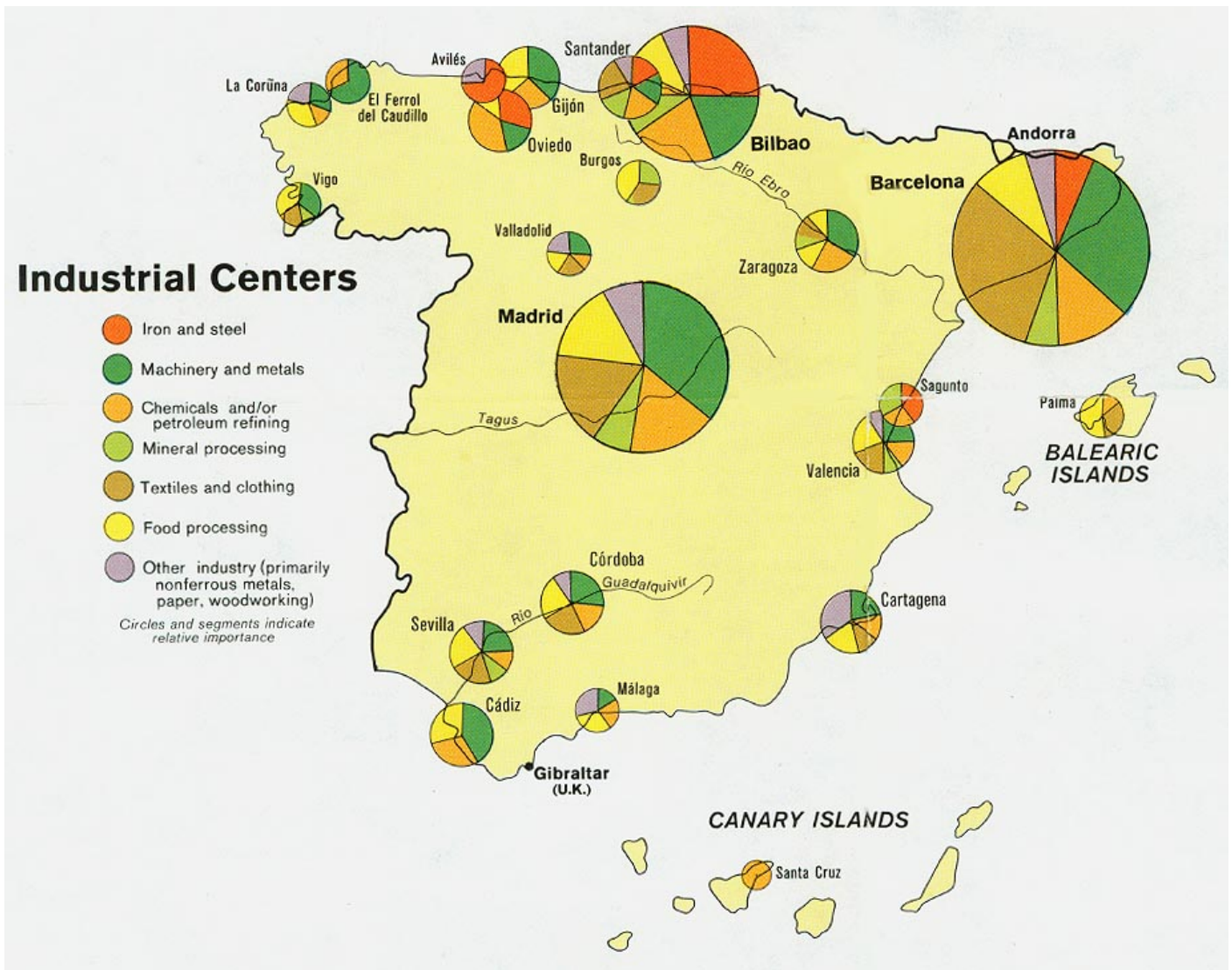

Figure 5. Industrial centers in Spain by 1974. Courtesy of the University of Texas Libraries, the University of Texas, Austin.

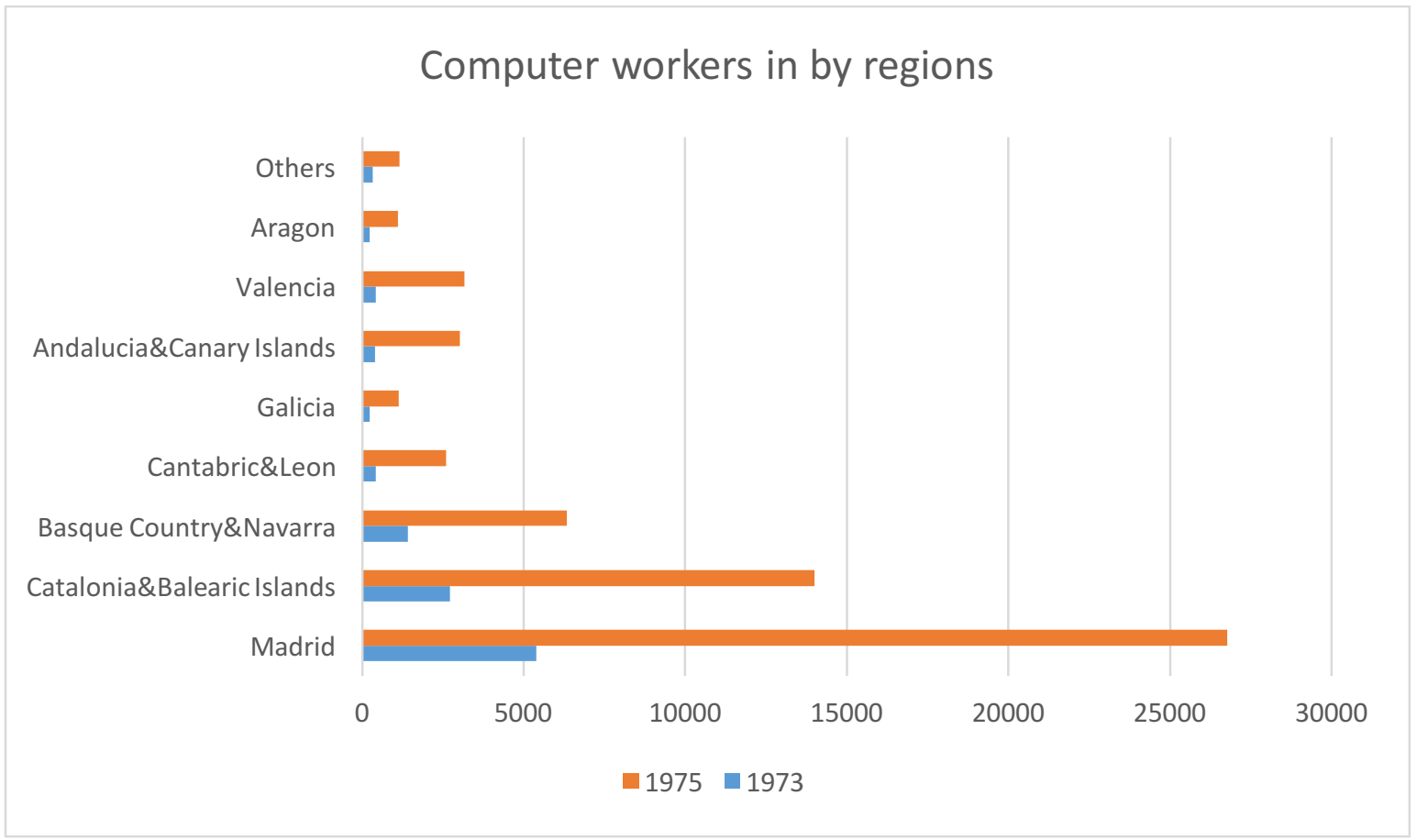

Figure 6. Computer workers by region in 1973 and 1975. Source: Presidencia del Gobierno, La informática en España, Servicio Central de Informática, 1973; Presidencia del Gobierno, La informática en España 1976, Servicio central de informática, 1977.

Many of ATI's members were active in the defense of computing workers' rights during the late 
Francoism. In the late 1960s, some of them infiltrated the OSE through its "diverse activities" branch. In December 1969, the regime counteracted this move by creating the National Autonomous Union Association of Informatics Professionals (Asociación Nacional Sindical Autónoma de Profesionales de la Informática, ANSAPI), a union that had its headquarters in Madrid and was closely controlled by the regime: the members of its board were designed by the president of the diverse activities branch, Juan García-Carrés ${ }^{33}$. However, in April 1972 the members of ATI who had started union activities were recognized as the board of the delegation of ANSAPI in Barcelona, which could be elected democratically ${ }^{34}$. This position allowed them to establish direct communication with the government and get information about ongoing regulating plans. On the other hand, it avoided tensions inside the ATI, shifting an important part of the political fight to the ANSAPI.

ANSAPI Barcelona early efforts were oriented against the Spanish government plans' to create an official professional guild (colegio profesional) of computer technicians, such as in other engineering professions, in which an official association membership was mandatory for all professionals and all members had to have a university diploma ${ }^{35}$. The reasons of this opposition can be found in article published in Novática, which in 1975 included the translation of an article by Philip Kraft that described professional guilds as examples of a strategy to divide works, and as a danger to worker's collective action ${ }^{36}$. This same argument was also expressed in a report evaluating the pros and cons of this new institution that concluded that it was created "to divide, to control and to frame" computer professionals, and that strict membership requirements would introduce class distinctions among computer people ${ }^{37}$.

\section{Legitimizing computer workers: ATI's opposition to the Instituto de Informática}

The second activity in which ATI and ANSAPI invested most efforts was the resistance to the Spanish government plans to regulate the training of computer professionals, which population was estimated around 45,000 people and that by the end of the decade could double this number ${ }^{38}$. In order to regulate this envisaged growth, the Spanish government aimed to make of computing one of the main lines of its fourth "development plan"39. This kind of instrument for macroeconomic planning had been conceived and implemented in the mid-1960 by mimicking the French "plans de modernization" created just after the Second World War, and were justified by the regime's new economic experts as a middle way between individual initiative and state planning. By the early 1970s, two development plans had been implemented in Spain (respectively for the periods 1964-67 and 1968-71) and a third one (for the period 1971-75) was on the run ${ }^{40}$. The last years of the regime coincided with discussions related to the fourth plan, for the period 1976-1979, which had to focus to some extent on the development of computing. In order to implement the plan, a committee on computing was established by the ministry of planning and development (Ministerio de Planificación y Desarrollo), counting with 64 members divided in 12 subgroups $^{41}$. The composition of these committees provides an interesting picture of the leaders and structure of the computing community and the selection bias related to its proximity to the regime. For example, $89 \%$ of members of these committees lived in Madrid and the rest of them in Barcelona (including the president of ATI). Almost all participants from Madrid worked in the public sector (army, government, university and public companies). In contrast, all of members of Barcelona worked in private companies (two computer manufacturers, one from banking, one automobile manufacturer and one from a software company) ${ }^{42}$.

As resulting of these discussions, one institution, the Madrid's Instituto de Informática, emerged as a potentially important instrument to put the new computing profession under state control. 
Established by decree in $1969^{43}$, the institute had officially the objective of coping with the "constant increment of electronic computers installed in the country" ${ }^{44}$. Independent of universities, its courses on computing followed the example of the British Computer Society professional grades, established in $1968^{45}$, and merely provided validation and certification of the grades acquired by professionals. In 1971, its curriculum was structured in 5 years, allowing for different grades: application programmer, system programmer, application analyst, and system analyst and system technician, the five categories prevailing at IBM at the time ${ }^{46}$.

The creation of the Instituto de Informática triggered a debate on the need of legitimating computer work as a profession. The institute's curriculum could have been a step towards professionalization, but the method established to regulate the access to the different categories in the computing profession had no consensus inside the profession: professionals felt they had been excluded and that, instead of fulfilling their aspirations, it hindered them. In fact, it can be argued that this climate of opposition was instrumental for the creation of the Catalan branch of ANSAPI: in summer 1971 the ATI had addressed an article to all computer professionals about the government plans to make the Instituto de Informática a key element in professional training. This document, signed by Albert Coromines ${ }^{47}$, was followed in autumn 1971 by a letter of complaint to the Minister of Education, announcing the activation of ANSAPI Barcelona, which had its foundational assembly in Barcelona in April 1972. The proceedings of this meeting show that the first decision to be implemented was to take legal actions against the Instituto de Informática, by arguing that $85 \%$ of computer people would be out of the profession according to the criteria of the institute ${ }^{48}$. The second one, in the same spirit, was to get collective agreements with companies to introduce computer labor categories without reference to the degrees implemented by the Instituto de Informática.

A second front in ATI's fight against the institute was to offer alternative training courses to IT technicians. Organized by the so-called "ATI's technical sections", they consisted seminars and conferences in the classrooms of the Engineering School of Barcelona about computer related topics -which sometimes lead to publications- and structured courses, not only oriented to commercial programming (which had more audience) ${ }^{49}$ but also to programming theory ${ }^{50}$. Although the number of activities was not stable year after year ${ }^{51}$, lecturers were often of high profile, including foreign computer specialists. In fact, most of the seminaries dealt with very innovative programming techniques at the time, explaining the state of the art and sometimes confronting different methodology schools. For instance, the ATI organized in 1974 a seminar entitled "Practical Applications of the Structured Programming", in which Manuel Costa, Eugenio Romero and Miquel Barceló spoke about improved programming technology operations, as well as Bertini and Warnier methods. Those activities also helped to build a shared vision of computing programming among the associates, which included a heterogeneous population, giving them not only the rudiments of specific manufacturers' products, but also knowledge of advanced programming techniques and a vision about the emerging discipline of computer science. 


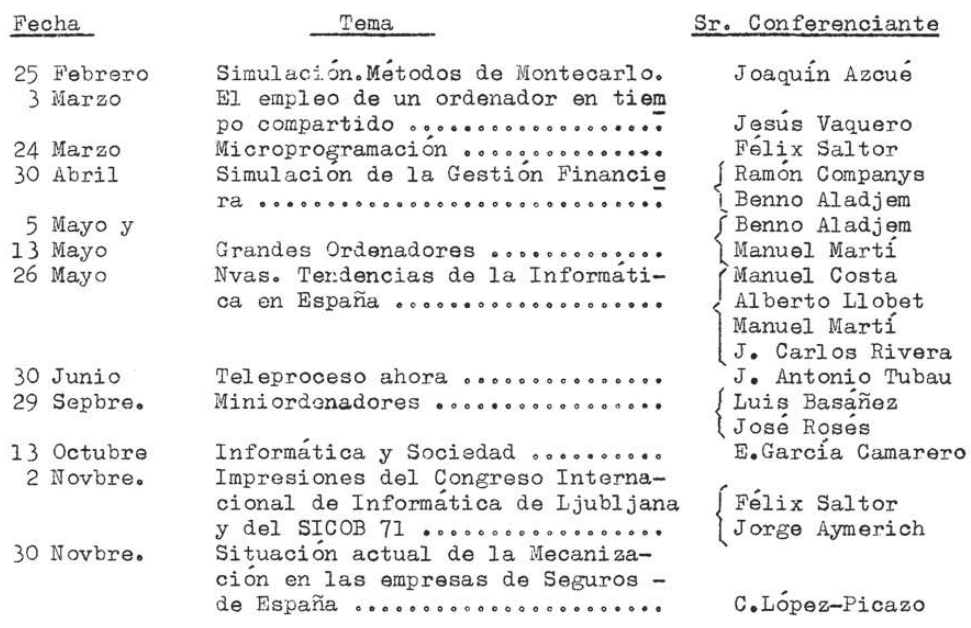

Figure 7. Seminaries held at the ATI in 1971. Source: ATI archives, http://www.ati.es/IMG/pdf/Asamblea_ATI 1972.pdf (retrieved 11 February 2015).

A committed and expanding community: the growth of ATI, Novática and political controversy

Opposition to the regime's plans regarding the profession and the climate of social unrest in late Franco's dictatorship contributed to the expansion of the ATI and to its engagement with current political controversies. For example, in October 1st 1975, while Franco was dying, far-right politic forces organized a violent street protest in Madrid to support the dictator. That same evening, six prominent members of the ATI decided to accelerate the creation of a delegation in Madrid the day after ${ }^{52}$. 50 people, recruited by the president of ATI, Ramon Puigjaner and ATI's Secretary, Xavier Berenguer, who had moved from Barcelona, attended the first session. At the same meeting, an Interim Board was created $^{53}$, and seven tentative rules were drafted, including one affirming ATI's independence of "any commercial entity" 54 .

In the following years, the ATI opened new locations and the number of its members grew dramatically. By the beginning of 1977, a delegate group of ATI was created in Valencia with 20 initial members. This same year, the ATI's membership had risen to 898 members in Catalonia (which was still the association's center of gravity), 251 in Madrid and 69 in the rest of Spain ${ }^{55}$. It included very different technical profiles, from manufacturers, to computer users, consultants or public servants. According to early ATI's coordinator Julian Marcelo-Cocho, they were attracted by the aforementioned tensions about workers' representation, professional legitimacy and training ${ }^{56}$.

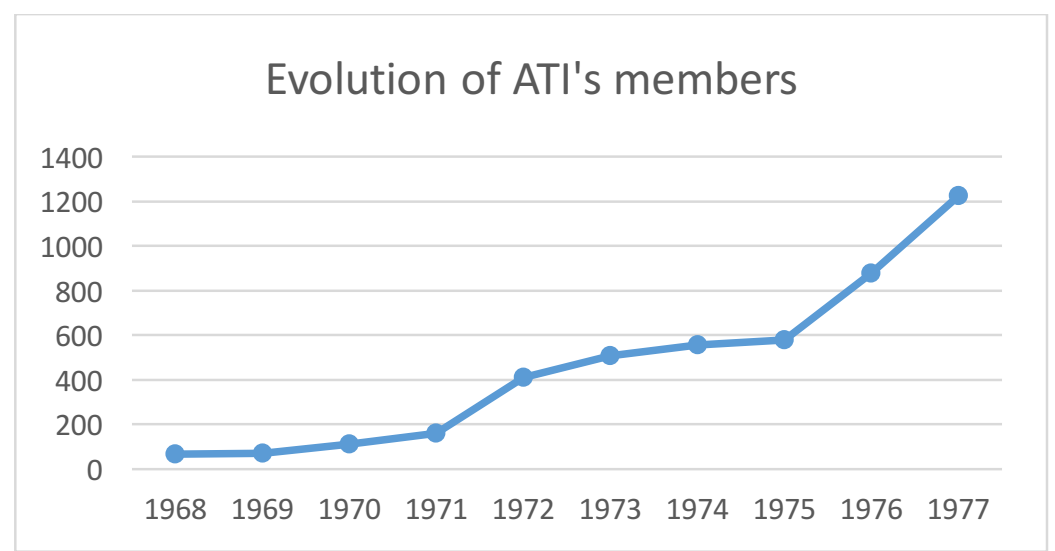


Figure 8. Evolution of the ATI's membership between December 1968 and December 1977. Source: Proceedings of ATI's meetings, ATI archives and Ramon Puigjaner personal archives.

The activities of the ATI cannot be only understood as arising of a desire of professional legitimization, but they were framed by the turbulent political context of Spain's transition to democracy and in a particular vision of computing. Many of the proposals concerning computer technicians' professional role were informed by an egalitarian ideology and the guidelines traced by communist trade-union CCOO. For example, the ATI refused that computer workers were segregated professionally by companies or governments from the rest of the workers, and defended collective negotiation between workers and company. In fact, there was a close articulation between ANSAPI and the CCOO: the ANSAPI coordinated the branches Oficinas $y$ despachos (software companies) and CCOO the Metal branch (hardware companies), its members being successfully elected in the last trade unions elections under the Francoist regime. With the new democratic regime, ANSAPI disappeared and its members could move to the new legalized trade unions.

Another evidence of the determined political agenda of the board of the ATI, well aligned with the strategies and values of left-wing forces in the late Francoism, can be obtained from the papers published in Novática, the association journal established in late 1974. The main goal of this publication was to act as a channel of expression of the association, and the themes addressed there were coherent with to the objectives of ATI's foundational regulations. Novática not only it had a section about computer science subjects, usually monographs, but also regular sections about social, technical and news issues. In these sections the tight relationship between ATI and ANSAPI Barcelona was also reflected in a regular section called "Workplace" (Mundo Laboral), which acted as ANSAPI newsletter since 1974. In this section, ANSAPI Barcelona tried to keep Spanish computer people aware of the profession problems in the near future, and informed them about any negotiation between companies and their Electronic Data Processing departments, new collective agreements, trade union elections or strikes. We find in the journal, for example, some critiques to create specific union for computer workers, and the recommendation that computer workers integrate the company's trade union to negotiate as a block with all other workers. At the same time, Novática's collaborators read American computer magazines and appropriated their concerns ${ }^{57}$.

Labor activities were not the only politically charged subjects addressed by Novática, whose articles alternated between utopian and dystopian images of computing, either warning about the threats of computing or expressing hopes in a future where computer will be able to improve and dignify human work and the human society in general. For example, the success of microcomputers over mainframes was considered positively, as it would imply less centralization and control that, under capitalism, will drive society towards an Orwellian dystopia ${ }^{58}$. Political events such as the Chilean use of computer for repression in 1975, which was closely followed by Novática $^{59}$, or the reference to French intellectuals such as Benjamin Coriat ${ }^{60}$, reinforced dystopian views, but in general these images were generally more optimistic than contemporary critics of computing.

At a more local level, Novática was a forum for at least three main controversies involving the position of the ATI regarding regional languages (and more specifically Catalan), its relations with the communist party and its position regarding data privacy. The first controversy, on August 1976, involved the reaction to the publication in the French journal Paris-Match of an interview with the Spanish Prime Minister and former member of Franco's government, Adolfo Suarez, in which he dismissed the possibility of using of Catalan language in Catalan schools ${ }^{61}$. At best, 
Suarez's declaration was a proof of ignorance from someone who had never been to Catalonia; at worst, it was an exercise of cynicism because the Francoist regime had tried, from the very beginning of the dictatorship, to restrict the use of Iberian languages other than Castilian ${ }^{62}$.

This interview was reproduced, in Spanish, by the right-wing newspaper $A B C$ a few days later. Almost immediately, several reactions took place. Newspapers like La Vanguardia, in Barcelona, received complaint letters and many professional organizations (the Catalan Society of Chemical and Physics Science and Mathematics and the professional association of Industrial Engineers, among others) expressed their disagreement ${ }^{63}$. Members of the ATI also participated in the controversy with the publication of an article in Novática that argued for equal opportunities for Catalan, Basque or Galician as for Castilian ${ }^{64}$. In reaction to this article, the Madrid publication Informática criticized the implication of the ATI in the controversy, considering that it played the role of a political party rather than of a professional association ${ }^{65}$. The journal asked rhetorically if ATI members were aware of their political membership and whether the ATI's rulers were elected according professional or political criteria, and finally argued that speaking Catalan would decrease professional expectations of computer professionals.

ATI's reply was published in a Novática's monographic on IT policy, in the section called "real time", usually written by Xavier Berenguer, which dealt with "computing and society" issues. The author remarked that other professional and scientific institutions had criticized Suarez's opinions, and they had not been accused of intromission on politics, that it was Informatica's blame to not be able to distinguish the difference of a professional association and a political party was, and that the ATI was a democratic institution, which democratically chose its board every two years ${ }^{66}$.

In this same year, Novática included indeed an editorial refusing the perceived left-wing ideological bias of the magazine. The ATI claimed for the unity of all the different computer people organizations was necessary to deal with its collective problems: training, validation of degrees and the lack of representation and not to translate the political fight methods to professional organizations ${ }^{67}$. On the other side, there is evidence that the association could not isolate itself from the left-wing political atmosphere prevailing in Catalonia. By 1977, coinciding with the first Spanish parliamentary elections in democracy, the communist Catalan Unified Socialist Party (Partit Socialista Unificat de Catalunya, PSUC) published a leaflet titled "Computing and Communists", in which the ATI was described as a collective heritage of all the professionals and workers in computing, in which "communists and others had invested a great deal of their energy", and computing was depicted as a key sector for consolidating democracy instead of a tool to increase the exploitation of the workers. The leaflet claimed for a better articulation of workers, strong professional associations -keeping the independence of the ATI, the hegemony of socialist ideas among professionals and workers of computing, and calling for reconsidering how computing should be in a democratic context ${ }^{68}$. The use of ATI's image concerned association members and it was discussed inside ATI's meetings ${ }^{69}$. Although board members were mostly supporters or even affiliates of the PSUC, they might have preferred the incident not to be repeated and to keep a more independent association ${ }^{70}$. In fact, there were only a few members of ATI affiliated to the PSUC, even if they occupied important positions in the ATI's board, and they not followed rigid consigns from the PSUC headquarters. They attachment to the party and the common solidarity arose principally their common activism and participation in subversive activities against the dictatorship, and some of them had even meet each as victims of the repressive policies of the regime ${ }^{71}$.

The third controversy in which the ATI was involved was related to the discussions about data privacy and computing in democracy, a debate that was especially relevant in the political 
transition. During Franco's dictatorship, several referenda had been held, but electoral fraud and vote rigging in favor of the regime were widespread. Thus, the organization of the first democratic elections required higher standards to legitimize the new regime, and that the first vote in liberty would be honest and transparent ${ }^{72}$. One of the elements invoked in assuring the honesty of the process was the use of electronic computers. State propaganda presented the computer in charge of counting the votes and processing the results (a Secoinsa-Telesincro IBER2) as a guarantee of transparency. At the same time, Secoinsa took the opportunity to promote its machine, as the "referendum computer" in newspapers ${ }^{73}$. The reaction of the ATI to this campaign highlighted, however, that a computer was an instrument, and that the reliability of the system could only be obtained by allowing citizen's and political representatives in the voting and vote counting process ${ }^{74}$.

By February of 1976, in an extraordinary general assembly, ATI had already discussed these issues among others related to computing, society and politics. As a result, the ATI approved a six-page long Manifiesto Informático, which provided a detailed picture of the development of computing in Spain. This manifesto discussed three main questions: the situation and needs of computer workers, the problems concerning training in computing, and the question of computing and individual liberty. In relation to this last aspect, the manifesto criticized Spain's technological dependence on the United States -which had been the main source of international support of Franco's regime- and asked that "democratic control mechanisms must be exist to control the central data bank of the Administration". Otherwise, the rights of the private life of the citizens would be in a serious danger. The ATI sent this manifesto to all major political authorities that had some decision power in computing affairs, from general directors to the King of Spain ${ }^{75}$.

ATI's interest in the question of computers and freedom reflected transnational debates on this issue, such as the discussions at the British Computer Society and the Association for Computer Machinery that led to the establishment of codes of conduct and a growing literature on the threats on privacy in the computer age ${ }^{76}$. By 1975, members of ATI had argued in Novática against a computerized register of individuals in Spain, relating the Chilean experience of "counter-insurgency computing" that had helped to detect leftists after the coup d'état in $1973^{77}$. The French project Safari, which aimed for the creation of a centralized database of personal data, also had a wide covering in Novática. The debates and conclusions of the national board created by France as a result of popular reaction against the project (Comision Nationale de l'Informatique et des Libertés, CNIL) were also closely followed in Novática ${ }^{78}$.

By 1977, the ATI tried to inform all the political forces about its concerns about the risks of using computers for processing and recollection of citizen's data. The ATI wanted that the new political parties took part in the development of computerization of Spain ${ }^{79}$, but also to make them aware of its potential misuses. Novática published two letters addressed to the Spanish Prime Minister Adolfo Suarez and to the Constitutional Commission, asking them to take into account the computing aspects of the use of individual data and the right of the society to access information. Indeed, Novática invited Catalan political parties with representation in the Parliament to use the journal as a board of discussion about computing and its socio-political implications ${ }^{80}$. The most remarkable success of this lobbying was the inclusion of an article in the draft of the Spanish Constitution, which asked that the use of computing should take into account the protection of "familiar and personal privacy". In the following negotiations, representatives of the center-right ruling party Unión de Centro Democrático tried to remove the article because they considered computers just as a specific type of instrument ${ }^{81}$, while other members of the commission arguing about its importance. Eventually, by an amendment of the 
Catalan representatives in the constitutional board -which had been subject to an intense lobbying from the ATI- the definitive version the Spanish Constitution included the following formulation: "The Law will restrict the use of computing to guarantee the familiar and personal privacy and citizens' honor and the full exercise of their rights" ${ }^{\prime 22}$. ATI's lobbying had succeeded to put, possibly for the first time in history, a reference to computing in a national constitution.

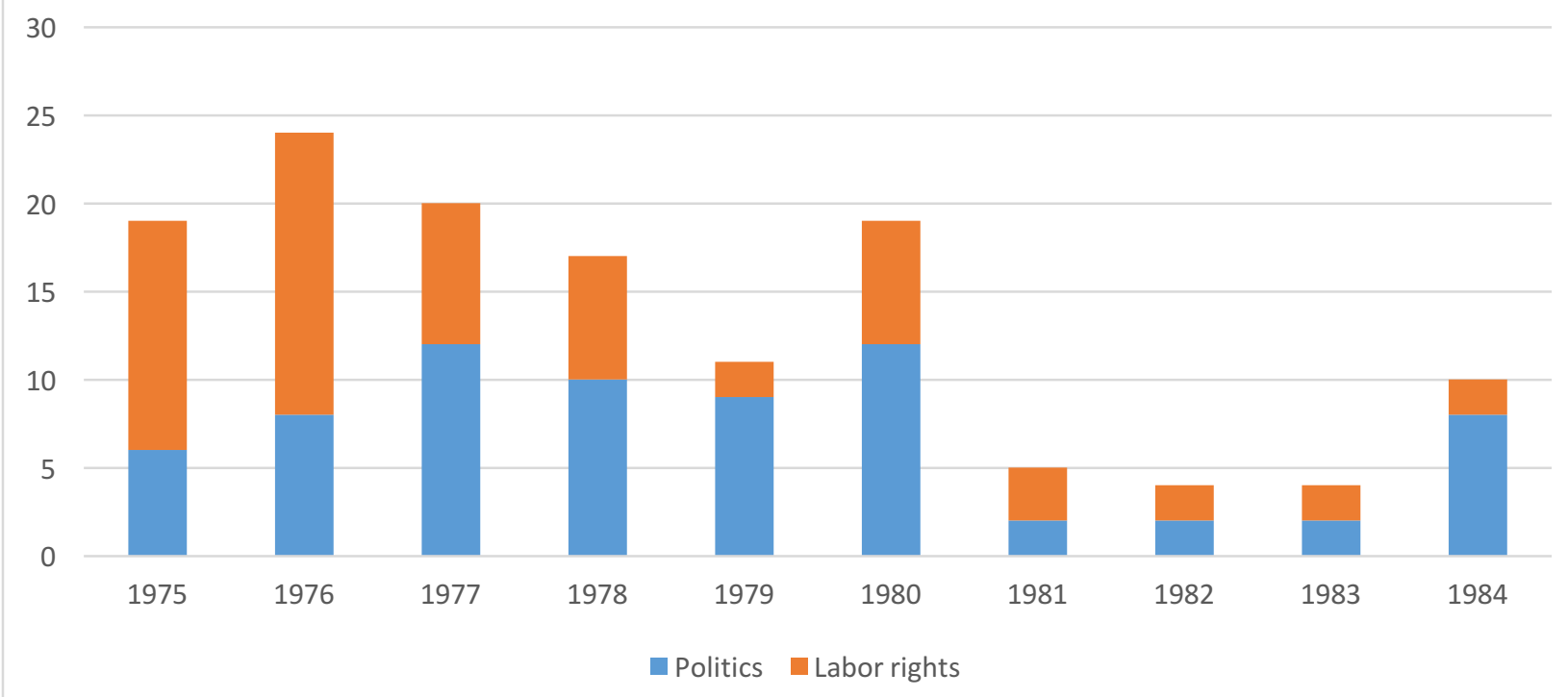

Figure 9. Articles published in Novática dealing with politics (blue) and professionalization (orange).

Political debate was thus prominent in Novática in the late 1970s. As shown in figure 9, the number of articles concerning political issues abounded, with important peaks in politically crucial moments such as the referendum of political reform of 1976, the first elections in democracy and the writing of the new Spanish Constitution (both in 1977). A last peak, in 1980, coincided with the election of the first autonomous government in Catalonia. Political issues were not disconnected from more technical discussions, as the leaders of the ATI repeatedly pointed out that projects like building a national computing industry or the creation of high degree studies in computer science ${ }^{83}$ required not only state support, but also the framework of a democratic state based on the rule of law ${ }^{84}$.

These turbulent years also reflected on the rapidly changing composition of the board: from December 1974 to August 1979, Novática had three directors (Julian Marcelo-Cocho, Josep Garriga and Arturo Moreno), but from until April 1987 just one (Francisco Iribarme) ${ }^{85}$. By then, lack of freedom and democracy was not a central problem anymore, computer science had achieved some recognition as a discipline and as a profession, and the political and social context had changed. The ATI achieved legal status in October 1979, the fourth development plan discarded by new democratic government, and most efforts of the members of the ATI were focused to the creation of computer science and engineering schools, to define standards of competency and devote themselves to the advancement of their professional careers ${ }^{86}$.

\section{Conclusion}

This paper has described the activities of the ATI in the 1970s, which combined demands for better working conditions in the computer industry and the promotion of academic programs in computer sciences with the lobbing to preserve privacy and personal freedom in the new Spanish Constitution. With political parties and unions forbidden by the regime, prominent members of the ATI found the association as a space of resistance to the dictatorship. ATI clearly 
identified itself with progressive, left-wing opposition to the Francoist regime in Catalonia during the political transition to democracy, and its members were well aware that computer science had not only technical consequences, but also social ones. ATI's claims and commitments were coherent with wider cultural, economic and political changes in the country, and were inspired by the climate of contemporary.

What this meant for the professionalization of computing in Spain? As several researchers have noted, in Europe and the United States the Information Technology sector grew without professionalization, nor unionism ${ }^{87}$ and, the case of the United States studies by Ensmerger, this could be explained by internal rivalries within the computing community and the lack of active support from employers. The Spanish case, however, is different in the sense that confronts different views of professionalization: on the one hand, a professionalization supported by the state and built on the exclusion of technicians non certified by the Instituto de Informática; on the other, the inclusive view supported by the ATI, which established a border with other professions were based in what people did, not in what they had studied, avoiding any previous barrier and, therefore refusing the creation of an official professional association. ATI's view also considered professionalization as a way of building skills and gain independence from the manufacturers, and most of its efforts went organizing courses and seminaries, which in the long run played an important role in the creation of the first university Spanish studies in Computer Science. Indeed, some of them spent the rest of their professional life in the academic arena. However, once the studies were established, the framework regulating professions had been replaced for a more liberal one, and official professionalization no longer was feasible, leaving software engineers as the only Spanish engineers without official rights and duties by law.

\section{Acknowledgments}

This article has been produced with the support of the project La física en la construcción de Europa (HAR2014-57776-P), funded by the Spanish Secretariat of Research, Development and Innovation. We thank two anonymous referees for their helpful comments.

\section{References and Notes}

${ }^{1}$ Created in 1963 by the scientific attaché to the French Embassy in Spain, the association had its headquarters in Madrid but all cultural activities (conferences, courses, etc.) were organized in Barcelona. Its main objective was to further exchanges between France and Spanish researchers, scientists and engineers. Well located in the center of Barcelona, it also acted as meeting point of former fellows of the association having completed their studies or research stages in France.

2 Established in 1863, The ANII was recognized by the Spanish state as a collaborator of the professional chamber regulating the access to the profession. It is important to stress that, in 1950, the ANII had merged with the Engineers' Guild (Colegio de Ingenieros) in Madrid, a semipublic institution charged with the regulation to the access to the profession. In Barcelona, both institutions coexisted: the Chamber collected fees from engineers and paid a rent to the ANII, owner of the building in which both institutions occupied. The ANNI used this money and other subventions from the Chamber to organize its academic and training activities.

${ }^{3}$ This is the case, for example, of the two first presidents of the ATI, Ramon Companys and Ramon Puigjaner. 
${ }^{4}$ The word informática comes from the book Informatik: Automatische Informationsverarbeitung by Karl Steinbuch, published in 1957, and it was introduced in Spain via the French "informatique". However, as Miquel Barceló has remarked, it was not adopted before 1965 (see Miquel Barceló, Una historia de la Informática, Editorial UOC, 2010). The word appeared in the Spanish press on July 21th 1965, in the Barcelonian newspaper La Vanguardia. The journalist wrote the word inside quotes, trying to explain the French Plan Calcul announced by De Gaulle: "Government action for the development of a national electronic calculators industry. It means positioning the nation in the age of 'informatics', rather strange word, but which determines the existence of a science". The administration did not use the word in its official publications until 1969 (BOE 14/04/1969), preferring before that the term mechanization, which subsumed hardware, software, and data processing mechanisms. A powerful inter-Ministerial committee called Comisión Interministerial de Informática was created in 1970, replacing the interMinisterial Committee on Mechanization created in 1968 (BOE 17/07/1968) with much more less defined attributions (BOE 20/10/1970). In any case, by 1967 it was still a neologism even for computing professionals. This is maybe one of the reasons why the foundation members of ATI added the term técnicos to the association name, rather than coining the new association as Asociación de informáticos,.

5 "Reglamento de la ATI, 4/10/1967". This source, and other documents in the archives of the ATI, is accessible online: www.ati.es/IMG/pdf/Reglamento ATI 4.10.1967.pdf (retrieved February 11th, 2016).

6 Political repression associated to Franco's dictatorship also retarded the reception of the European social and cultural transition process epitomized by the French May 1968, and it unfold in parallel to the change of regime. See Tony Judt, Postwar: A History of Europe since 1945, Random House, 2011; and Carl Boggs, Social Movements and Political Power: Emerging Forms of Radicalism in the West, Temple University Press, 1989.

7 Slava Gerovitch, From Newspeak to Cyberspeak: A History of Soviet Cybernetics, MIT Press, 2004.

${ }^{8}$ Paul N. Edwards, The Closed World. Computers and the Politics of Discourse in Cold War America, MIT Press, 1997.

${ }^{9}$ Fred Turner, From Counterculture to Cyberculture : Stewart Brand, the Whole Earth Network, and the rise of Digital Utopianism, University of Chicago Press, 2006.

${ }^{10}$ Eden Medina, Cybernetic Revolutionaries: Technology and Politics in Allende's Chile, MIT Press, 2011.

${ }^{11}$ Andrew Abbott, The system of profession. An Essay on the Division of Expert Labor, University of Chicago Press, 1988.

${ }^{12}$ Nathan L. Ensmenger, The computer boys take over: Computers, programmers, and the politics of technical expertise, MIT Press, 2010, pp. 235-236.

${ }^{13}$ Stephen Barley, "Technicians in the Workplace: Ethnographic Evidence for Bringing Work into Organization Studies", Administrative Science Quarterly, vol. 41, 1996, pp. 404-411.

${ }^{14}$ Xavier Berenguer, A. Corominas \& J. Garriga, "Sindicación de los informáticos: por qué y cómo", Novática, vol. 2, 1975, pp. 5-11.

${ }^{15}$ This approach also connects with the spirit of the Industrial School of Barcelona, were a lot of Catalan members of the ATI were studied. According to Esteve Terrades, first director of the Institute of Applied Mechanic and Electricity at this school, "The graduated students in this school, would have the brains agile and disciplined; necessary technical erudition; the indispensable general knowledge; but also, and this is important, calloused hands". Cited in: 
Francesc X. Barca et al., L'Escola Industrial de Barcelona (1904-2004): cent anys d'ensenyament tècnic i d'arquitectura, Diputació de Barcelona, 2008, pp. 83-84.

${ }^{16}$ This paper is based in part in the personal archives of the Professor Ramon Puigjaner as well as several interviews with members of ATI and professors of the first university schools in computing in Spain. For example: Jesús Rodríguez-Cortezo, founding member of ATI-Madrid and manager at the National Institute of Industry (INI); Julian Marcelo-Cocho, first director of Novática and member of the Intergovernmental Bureau for Informatics (IBI-UNESCO); Fernando Piera-Gómez, secretary of the Instituto de Informática and also member of the IBI and the ATI; Ramon Puigjaner, president of the ATI, employee UNIVAC and dean of the Facultad de Informática de Barcelona (FIB) at the Technical University of Catalonia (UPC); Miquel BarcelóGarcía, employee of Bull and professor at the FIB; Antoni Olivé, employee of Seresco and professor at the FIB; and Ton Sales, employee of IBM before becoming professor at the FIB. All this material is being prepared to be in open access at http://ddd.uab.cat. In the meanwhile, there are copies of some of the documents in the ATI's archive, which are accessible in the association website (http://www.ati.es), thanks to the efforts of one of the ATI founding members, Miquel Sarries.

17 Jaume Nadal, España: 200 años de tecnología, Ministerio de Industria y Energía, 1988.

18 H. D. Köhler, El movimiento sindical en España: Transición democrática. Regionalismo. Modernización económica, Fundamentos, 1995. José Babiano has nuanced this view by stating that the OSE had in practice a minor role, and employers and even the clandestine union Comisiones Obreras (CC.OO.) were much more important in the negotiation of the collective agreements. José Babiano, "¿Un aparato fundamental para el control de la mano de obra? (Reconsideraciones sobre el sindicato vertical franquista)", Historia Social, vol. 30, 1998, pp. 2338. Other authors, such as H. R. Morgan, had even described the OSE more as a kind of guild than a trade-union. H. Morgan, Fascism, Integralism and the Corporative Society, Xlibris, 2014.

${ }^{19}$ In the late Francoism, the Communist party was the most important group opposing the regime. However, the legalization of political parties after Franco's death fostered the hegemony of the Socialist Workers Party (PSOE), which despite it radical language rejected Marxism and became a centrist, social-democrat member of the Socialist International. The PCE, which abandoned Leninism and approached Eurocommunism, was increasingly marginalized in the post-Franco political game. See: Enrique Moradiellos, La España de Franco (1939-1975), Síntesis, 2003; and Juan Antonio Andrade-Blanco, "Renuncias y abandonos en la evolución ideológica durante la transición a la democracia: una propuesta para el estudio del IX Congreso del PCE y el Congreso Extraordinario del PSOE", Historia Actual Online, vol. 8, 2005, pp. 43-50. See Joe Foweraker, Making Democracy in Spain: Grass-Roots Struggles in the South, 1955-1975, Cambridge University Press, 1989. Far from being a mere transmission belt of the communist directives, CCOO assumed sometimes the role of a political party, orienting their activities towards broader political objectives. See Miguel Martinez Lucio, "Trade unions and communism in Spain: The role of the CCOO in the political projects of the left", The Journal of Communist Studies and Transition Politics, vol. 6, no. 4, 1990, pp. 80-99.

${ }^{20} \mathrm{BOE}, 25^{\text {th }}$ April 1958.

${ }^{21}$ Ley 104/1965, de 21 de diciembre, sobre modificación del artículo 222 del Código Penal (BOE, 23 December 1965, pp. 17219-17219. Under this law, strikes that altered "the state's security" were still considered as seditious. 
${ }^{22}$ The ABC newspaper, on March 20th 1955, highlighted IBM and its electronic calculator for data processing. By then, IBM in Spain had around 800 machines installed (no electronics), including seven departments of the Government and 64 companies.

${ }^{23}$ IBM campaigns were aggressive and included very expensive showrooms. The IBM 360/20 travelled in a specially adapted plane, in the so-called CompuTour. It landed in Barcelona in 1965 and, according to the local press, it draw huge crowds. The IBM sales department distributed whisky during queuing time so generously that in Spain it was renamed as the "booze-tour".

${ }^{24}$ See Jacques Maisonrouge, Inside IBM: A European's Story, Collins, 1988.

25 Luis Sanz-Menendez, "Technology policy in Spain: issues, concerns and problems". In: G. Aichholzer \& G. Schienstock, eds., Technology Policy: Towards an Integration of Social and Ecological Concerns, de Gruyter, 1994, pp. 349-374.

${ }^{26}$ See: J. Nadal, España: 200 años de tecnología, Ministerio de Industria y Energía, 1988, p. 167.

27 Ton Sales, "La informática comercial española en la primera década (1960-1970): Apuntes para una historia de la informática en España", Novática, vol. 34, 1980, pp. 53-59.

${ }^{28}$ The success of the 1401 model is attested by the sale of 12,000 units worldwide and, according to Martin Campbell-Kelly and William Aspray, was not due to its computing power, but to IBM engineers holistic approach, which took into consideration the transition schedule, the training of users, maintenance and logistics, as well as the introduction of a new programming language (Report Generator Programming, RGP) that users accustomed to wire tabulators plug board could learn in a couple of days. See Charles J. Bashe, Lyle R. Johnson, John H. Palmer, and Emerson W. Pugh, IBM's early computers. A Technical History, Cambridge, MA: MIT Press, 1986, pp. 465-474, and Martin Campbell-Kelly, William Aspray, Nathan Ensmenger, \& Jeffrey R. Yost, Computer. A History $f$ the Information Machine, Westview Press, 2013, pp. 118-121.

${ }^{29}$ Presidencia del Gobierno, La informática en España, Servicio Central de Informática, 1973.

30 Nathan L. Ensmenger, The Computer Boys Take Over: Computers, Programmers, and the Politics of Technical Expertise, MIT Press, 2010.

31 The first collective agreement was signed in March 1970 (BOE 4/3/1970) in Bull General Electric, S.A., becoming a model for future collective agreements. Luis Arroyo, 200 años de informática, Espasa Calpe, 1991. The Spanish government did not deal with the computing workers in the public sector before the Honeywell Bull collective agreement of 1976 except for the case of army, which since 1972 had established a hierarchy for the IT workers in the military. However, specific laws about automatic mechanization of the government existed since 1952, and the "progressive automation and mechanization" was a specific target for the administration of the state since 1958. Source: Presidencia del Gobierno, La informática en España 1976, Servicio central de informática, 1977.

32 Resistance to the regime combined the left-wing worker's movements, fostered by the high concentration of industrial workers in Barcelona and its industrial belt, and Catalan nationalism. Heavily repressed during Franco dictatorship, both movements were often articulated. For example, the communist-led union Comisiones Obreras participated since 1967 in the clandestine commemorations of September 11th Catalonia's national day. Daniele Conversi, The Basques, the Catalans, and Spain: alternative routes to nationalist mobilization, University of Nevada Press, 2000.

${ }^{33}$ García-Carrés, which was a member of the puppet Francoist parliament, would become famous during the transition by its implication in far-right terrorism. He had an active role, for example, in Colonel Tejero's coup d'état in 1981, being the only civilian convicted after the coup failure. 
${ }^{34}$ Members of ATI close to the communist underground movement profited this opportunity to infiltrate the union, which was the strategy commonly supported by the clandestine union Comisiones Obreras. The members of ATI in the board were Miquel Sarriés, who was elected as secretary, and Julian Marcelo-Cocho. They profited from a legal framework approved in 1958, which allowed some elected representatives. On the effects of this law on the evolution of worker's rights under Franco, see Enrique Moradiellos, La España de Franco (1939-1975), Síntesis, 2003.

35 The system of professional associations in Spain was similar to the French ordres professionnels, the Italian ordini e i college professionali or the German bundeskammer, i.e., private institutions of public interest which main goal was regulating the access to the profession. For a comparative case study see José Luis Carro-Fernández-Valmayor, "La problemática de los colegios profesionales en el derecho comparado (Francia, Italia, Alemania)". In: Luis Martín-Portillo, Los colegios profesionales a la luz de la Constitución, Civitas, 1996, pp. 2066.

${ }^{36}$ Philip Kraft, "Programando al programador", Novática, vol. 6, 1975, pp. 19-21. This is a translation of his article "Pushing Professionalism [or] Programming the Programmer", Science for the People, vol. 4, 1974, pp. 26-29. The Science for the People magazine appeared twice a month in the US from 1979-1989, Marxist-oriented, tackled, for example, the progressive militarization of scientific research or environmental implications of energy policy.

37 Julian Marcelo-Cocho, "Los informáticos (una historia de la profesión)", Novática, vol. 34, 1980, pp. 61-66.

38 Without considering key-punch operators (which doubled the amounts), counts ranged between 36,652 (according to García-Alarcó, 1972) and 48,000 people (according to ATI Madrid, 1973). In middle ground, the committee of the IV Plan counted 42,888 people in 1974 , and in 1975 the company ENTEL estimated this population in 41,841. These numbers led experts to predict that this progression would continue in the near future to reach more than 100,000 computer workers by 1979. Presidencia del Gobierno, La informática en España 1976, Servicio central de informática, 1977.

${ }^{39}$ For some authors (see Jaume Nadal, España: 200 años de tecnología, Ministerio de Industria y Energía, 1988) Spanish development plans were, indeed, a setback after the stabilization plan. For others, they were just an excuse to claim credit for the years of expansion of the Spanish economy (see Ramón Tamames, Estructura económica de España, Alianza Editorial, 2008).

40 The first and second plan had focused respectively on investment and export (see Emilio De Figueroa, "Análisis prospectivo y retrospectivo de la planificación en España", Arbor: Ciencia, Pensamiento y Cultura, 1969, vol. 84, pp. 19-36). The third plan focused on the expansion of telephony (see Ángel Calvo, Telecomunicaciones y el nuevo mundo digital en España, Ariel, 2014). ${ }^{41}$ As in previous plans, the goals to be achieved and the measures to be taken were discussed in committees involving experts in different sectors. Once the plan was delivered, they had to inform the government about the execution, always related to their respective areas of knowledge. Every Plan had two parts: one was indicative (sector related projections in general), the other one was binding, as long as it was the program of public investments. According to economist Ramon Tamames, this organization was never implemented in practice: public investment programs were never fully implemented and the selection of participants was quite arbitrary, not following criteria of corporate importance, but of political influence.

${ }^{42}$ Ramon Puigjaner personal archives. 
${ }^{43}$ The decree 554/1969 (BOE 14 April 1969) established the Instituto de Informática under the Ministry of Education and Science, based in Madrid.

${ }^{44}$ The press conference of the Ministry Council on March 21 of 1969 was all completely devoted to the end of the state of exception, but Minister Manuel Fraga-Iribarne took a moment to announce the creation of the Instituto de Informática. See: "Se levanta el estado de excepción en todo el territorio nacional", ABC Sevilla, 22 March 1969, p. 29.

${ }^{45}$ On the development of computer science studies in Western countries, see: Martin Clark, "State Support for the Expansion of UK University Computing in the 1950s," IEEE Annals of the History of Computing, vol. 32, no. 1, 2010, pp. 23-33; or Jon Agar, "The Provision of Digital Computers to British Universities up to Flowers Report (1966)," The Computer Journal, vol. 39, no. 7, 1996, pp. 630-642; William Aspray, "Was Early Entry a Competitive Advantage? US Universities That Entered Computing in the 1940s," IEEE Annals of the History of Computing, vol. 22, no. 3, 2000, pp. 42-87; Pierre Mounier-Kuhn, L'Informatique en France de la seconde guerre mondiale au Plan Calcul. L'Émergence d'une science, Presses de I'Université Paris-Sorbonne, 2010; Pierre Mounier-Kuhn, "Computer Science in French Universities: Early Entrants and Latecomers", Information and Culture, vol. 47, no. 4, 2012, pp. 414-456. For the Spanish case, see Jordi Fornes \& Nestor Herran, "Computing in transition: the origins of Barcelona's School of Informatics, 1976-1984", Annals of the History of Computing, IEEE 36, no. 1, 2014, pp. 18-29.

46 BOE, 14 April 1969. By 1972 the Spanish market was dominated by IBM (67\%), followed by Honeywell-Bull (11\%), Univac (9.5\%), and NCR (8.5\%).

${ }^{47}$ Coromines, which was one of the founders of ATI, was also member of the clandestine communist party Catalan Unified Socialist Party (Partit Socialista Unificat de Catalunya, PSUC), which led in early 1970s the democratic opposition to the Francoist regime.

48 Assembly of creation of ANSAPI Barcelona. ATI archives, available online at: http://www.ati.es/IMG/pdf/Acta_Creacion_ANSAPI.pdf (retrieved 11 February 2015).

${ }^{49}$ Several conferences dealing with "data Banks" were very successful. Among the invited lecturers there was, for example, William T. Olle.

${ }^{50}$ The first one, in 1968, by Vicent Trixier.

51 The number of activities was: twelve in 1971, with subjects like "Montecarlo methods in simulation" or "Teleprocessing"; seven in 1972, on more academic topics, with titles like "Virtual memory" or "Mainframe architectures", and five in 1973, but only two in 1974 and back to 7 in 1976.

52 Not only ATI reacted to this events. The Catalan branch of the ANII organized an urgent meeting on 3 October 1975 and wrote a press release rejecting the use of violence and the death penalty, arguing for the democratization of the political structure. Official records of the extraordinary governing board of the ANII in Catalonia, held on 3 October 1975. Ramon Puigjaner personal archives.

53 The members of this board were Pedro García Alarcó, Jesús Rodríguez Cortezo, Rafael Fernández Calvo, Carlos Avecilla Riancho, Angel Reviejo Lobato and Juan-Francisco Perez Carballo.

${ }^{54}$ ATI's Assembly of creation of Madrid's group, 1975. Ramon Puigjaner personal archives.

55 Not only new members flocked, but fidelity was high. For instance, from 9 to 13 December 1976, there were fifteen new memberships from twelve different companies and ten different cities, but only three left the association. ATI's adds and removes on December 1976. Ramon Puigjaner personal archives. 
${ }^{56}$ In a letter dated on 14 January 1977, Marcelo-Cocho compared ATI with associations like ACM, AFIRO, BCS or IFIP and he argued the necessity of a delegation in Valencia because of a twofold argument: on the one hand, the revolution of micro computing would imply a huge reconversion of the computer people (and therefore ATI members would need local courses and seminars); on the other hand, the first steps for the creation of an school of computer science in Valencia were taking place and ATI had to be present to deal with the new professional problems and opportunities. Letter of creation of ATI Valencia, dated in 1977 and signed by Julian MarceloCocho. Ramon Puigjaner personal archives.

57 An example of this is the commentary of an article published in Datamation magazine (Bernhard Schwab \& Mark Thompson, "Unionism in data processing", Datamation, vol. 20, num. 10, 1974, pp. 61-69) by two associate professors at the University of British Columbia discussing managerial implications of white collar unionism in computing. Addressed to managers, it raised concern about the impact that a strike involving relatively few employers in a data processing department could inflict to a company, advising managers to "keep the union out of your data processing department". The author of the article criticized this opinion, but at the same time considered that those movements very incipient in Spain (Xavier Berenguer, Albert Coromines, and Josep Garriga, "Sindicación de los informáticos: Por qué y cómo", Novática, vol. 2, 1975, pp. 5-11.)

${ }^{58}$ Xavier Berenguer, "El PSF y la informática", Novática, vol. 10, 1976, pp. 51-52.

${ }^{59}$ Xavier Berenguer, "La infomática antisubversiva", Novática, num. 1, 1975, pp. 38-39.

${ }^{60}$ Benjamin Coriat, Science, technique et capital, Seuil, 1976

${ }^{61}$ Asked if Catalan would be used in High School, as a step of democracy restoration, Suarez answered that it was a stupid question because the interviewer would not be able to find anybody who could teach science in Catalan.

62 Jaume Claret-Miranda, El atroz desmoche: la destrucción de la Universidad española por el franquismo, 1936-1945, Crítica, 2006.

63 "Nuevas muestras de disconformidad por las declaraciones del Presidente Suarez a Parismatch", La Vanguardia, September 3, 1976, pp. 25.

${ }^{64}$ The ATI tried to have the widest possible consensus with the language issue. There is also evidence that participants in seminars in Catalonia had the choice of receiving documentation in Castilian, in Catalan or in both languages. Letter dated 1976, signed by M. Sanz, Ramon Puigjaner personal archives.

${ }^{65}$ The Journal Informática was a semi-official government journal focusing on computing. It was managed, as private business, by two army engineers: Eugenio Sánchez Ballesteros and Angel Saltó-Dolla.

${ }^{66}$ Xavier Berenguer, "ATI, desde luego, no es un partido político". Novática, vol. 12, 1976, pp. 39-41.

67 J. Garriga, “Editorial”, Novática, 1976, March-April, pp. 2.

68 The document said: "I'articulació d'una hegemonia de treballadors i professionals de la informàtica pel socialisme en la llibertat és el resultat buscat i pel qual lluitem". PSUC propaganda leaflet, dated 1977, Ramon Puigjaner personal archives.

${ }^{69}$ In the notice of the ATI board's meeting, dated on $17^{\text {th }}$ of June of 1977 and signed by the President of ATI, Ramon Puigjaner, the subject was introduced in the session contents. Ramon Puigjaner archives.

70 The PSUC obtained more than an half million of votes $(18,31 \%)$ in Catalonia in the first general elections of that year (see http://governacio.gencat.cat/), becoming the second most voted 
political force in the region after the Socialist Party. No document exists about the actual position of the board of the ATI regarding the question; the stated position is inferred from an interview with Julian Marcelo Cocho.

${ }^{71}$ For instance, Julian Marcelo-Cocho, from Madrid, and Miquel Sarriés from Barcelona, both members of clandestine student organizations at the University, had to spent their military service in the navy among private soldiers, rather than second lieutenants, the rank that they deserved as university students. That was a typical penalty for subversive activities for graduate students. That, automatically, let them to meet and establish an enduring friendship.

72 R. Del Águila, La dinámica de la legitimidad en el discurso político de la transición. In: R. Cotarelo, Transición política y consolidación democrática. España (1975-1986), Madrid: CIS, 1992, pp. 47-75.

${ }^{73}$ The Secoinsa-Telesincro ad appeared at the newspapers $A B C$ Madrid on December 19, page 12 and two days later at $A B C$ Sevilla, page 21 and La Vanguardia, page 42.

74 “Ordenadores y política”. Novática, vol. 13, 1977, pp. 39-40.

75 Archives of the ATI hold the following letters acknowledging reception of the Manifesto: on May 4, from the Ministry of Trade Unions Relations, Rodolfo Martín Villa. On May 24, from the Ministry of Science and Education, Carlos Robles Piquer. On April 10 from Zarzuela Palace signed by Rafael de Valenzuela, from de House of the King. On April 7, from Gabriel Ferraté Pascual, General Director of Research and Universities. On April 9, from Manuel Arroyo Quiñones, General Director of Apprenticeship, Ministry of Science and Education. Ramon Puigjaner archives.

${ }^{76}$ A. R. Miller, "Personal Privacy in the Computer Age: The Challenge of a New Technology in an Information-Oriented Society", Michigan Law Review, 1969, pp. 1089-1246 and L. J. Hoffman, "Computers and privacy: A survey", ACM Computing Surveys (CSUR) 1.2, 1969, pp. 85-103. Some similarities regarding its position on privacy can also be established between Novática and the predecessors of Wired magazine.

77 Xavier Berenguer, "La informática antisubversiva”, Novática, 1975, pp. 38.

78 "La informática y la política", Novática, vol. 6, 1975, pp. 43-45. The CNIL was established in 1978 to guarantee that the collection, storage and use of personal data was made according to the law.

79 Josep Garriga, "Editorial”, Novática, vol. 17, 1977, p. 4.

80 "Carta a los partidos políticos", Novática, vol. 17, 1977, pp. 53.

${ }^{81}$ R. Escobar, "Informática y derecho a la intimidad", Novática, vol. 33, 1980, pp.5-15.

82 BOE, 29 December 1978, pp. 29313-29424. The original versión of the article (in Spanish) states: "La ley limitará el uso de la informática para garantizar el honor y la intimidad personal y familiar de los ciudadanos y el pleno ejercicio de sus derechos".

83 In 1975, Novática published a detailed proposal for a computer science academic course (Ramon Puigjaner \& M. Vergés, "Bases para un plan de estudios", Novática, vol. 5, 1975, pp. 512.). When democracy was established, this proposal became the outline for the first grade in computer science at the Polytechnic University of Barcelona (UPB). The first Spanish university degrees in computer science were designed to grand extent by professionals connected to the ATI. In the autumn of 1974, Gabriel Ferrate Pascual, by then chancellor of UPB, arranged a dinner at his home. Ferraté, a professor of automatics since 1965, had been the director of the School of Industrial Engineering from 1969 until 1972, when he became chancellor. From this position, he participated in the commission to report on the training in computing in Spain. His partners at the meeting were also members of UPB: the mathematician Enric Trillas and an industrial 
engineer Ramon Puigjaner, who also was the president of the ATI. They talked about the Instituto de Informática and the background of IT studies in Spain. They eventually decided to prepare a five-year curriculum that was based in the ACM's 1968 proposal, and as far as possible from the one proposed by the Instituto de Informática. Ferraté's henchmen completed a draft of the official curriculum, which was approved by governmental decree in 26 March 1976. The legal text also included the appointment of another prominent member of the ATI, the statistician Martí Recober, as dean.

${ }^{84}$ Josep Garriga, "Editorial”, Novática, vol. 12, 1976, pp. 2-4.

85 The list of the directors of the journal Novática is available online: http://www.ati.es/novatica/2000/145/directores-145.html (retrieved 11 February 2016).

${ }^{86}$ Jordi Fornes \& Nestor Herran, "Computing in transition: the origins of Barcelona's School of Informatics, 1976-1984", Annals of the History of Computing, vol. 36, num. 1, 2014, pp. 18-29.

${ }^{87}$ See Ulf Hashagen, Reinhard Keil-Slawik, \& Arthur L. Norberg, eds. History of Computing: Software Issues: International Conference on the History of Computing, Springer, 2002. 